\title{
The consequences of nuclear transfer for mammalian foetal development and offspring survival. A mitochondrial DNA perspective
}

\author{
Justin C St John, Rhiannon E I Lloyd, Emma J Bowles, Emma C Thomas and \\ Shahinaz El Shourbagy
}

The Mitochondrial and Reproductive Genetics Group, The Division of Medical Sciences, The Medical School, The University of Birmingham, Birmingham B15 2TT, UK

Correspondence should be addressed to Justin C St John, Room EF20, The East Wing, The Medical School, The University of Birmingham, Birmingham B15 2TJ, UK; Email: j.stjohn@bham.ac.uk

\begin{abstract}
The introduction of nuclear transfer (NT) and other technologies that involve embryo reconstruction require us to reinvestigate patterns of mitochondrial DNA (mtDNA) transmission, transcription and replication. MtDNA is a 16.6 kb genome located within each mitochondrion. The number of mitochondria and mtDNA copies per organelle is specific to each cell type. MtDNA is normally transmitted through the oocyte to the offspring. However, reconstructed oocytes often transmit both recipient oocyte mtDNA and mtDNA associated with the donor nucleus. We argue that the transmission of two populations of mtDNA may have implications for offspring survival as only one allele might be actively transcribed. This could result in the offspring phenotypically exhibiting mtDNA depletion-type syndromes. A similar occurrence could arise when nucleo-cytoplasmic interactions fail to regulate mtDNA transcription and replication, especially as the initiation of mtDNA replication post-implantation is a key developmental event. Furthermore, failure of the donor somatic nucleus to be reprogrammed could result in the early initiation of replication and the loss of cellular mtDNA specificity. We suggest investigations should be conducted to enhance our understanding of nucleo-cytoplasmic interactions in order to improve NT efficiency.

Reproduction (2004) 127 631-641
\end{abstract}

\section{Introduction}

Nuclear transfer (NT) involves the fusion of either an embryonic or somatic donor cell with an enucleated recipient oocyte (Campbell et al. 1996). The resultant reconstructed oocyte can then be activated electrically or biochemically and allowed to develop in culture. Viable embryos, from various stages of development, are then transferred into surrogates. However, this technology is fraught with low success (Wilmut et al. 1997). In the case of Dolly, the first cloned sheep derived from Somatic Cell NT (SCNT), the generation of 283 embryos resulted in one viable offspring. Although offspring from various species are now produced with a greater intensity, it is still evident that these offspring are liable to serious defects (Cibelli et al. 2002). These include phenotypes such as circulatory distress, placental oedema, umbilical hernia, hydrallantois, respiratory problems, immune dysfunction and kidney/brain/liver malformation. Furthermore, large offspring syndrome is associated with bovine and ovine offspring and involves pathological changes such as extended gestation length and increased birthweight (Lazzari et al. 2002). However, very few of the pathologies reported have taken mitochondrial dysfunction into consideration but closer analysis suggests that mitochondrial disorder might indeed persist. Examples include myopathies and liver disorders (see Cibelli et al. 2002). The aim of this review is to analyse the potential impact that aberrant mitochondrial DNA (mtDNA) transmission can have on NT outcome and how modifications to its transmission could result in potentially greater success. It also emphasises the importance of nucleo-cytoplasmic interaction and nuclear reprogramming to mtDNA differentiation.

\section{The role of mitochondria}

Mitochondria are the key generators of cellular ATP. ATP can be produced through the Kreb's cycle, $\beta$-oxidation and oxidative phosphorylation (OXPHOS). In the vast majority of cases, the primary pathway for ATP production is OXPHOS via the electron transfer chain (ETC; see Fig. 1), 


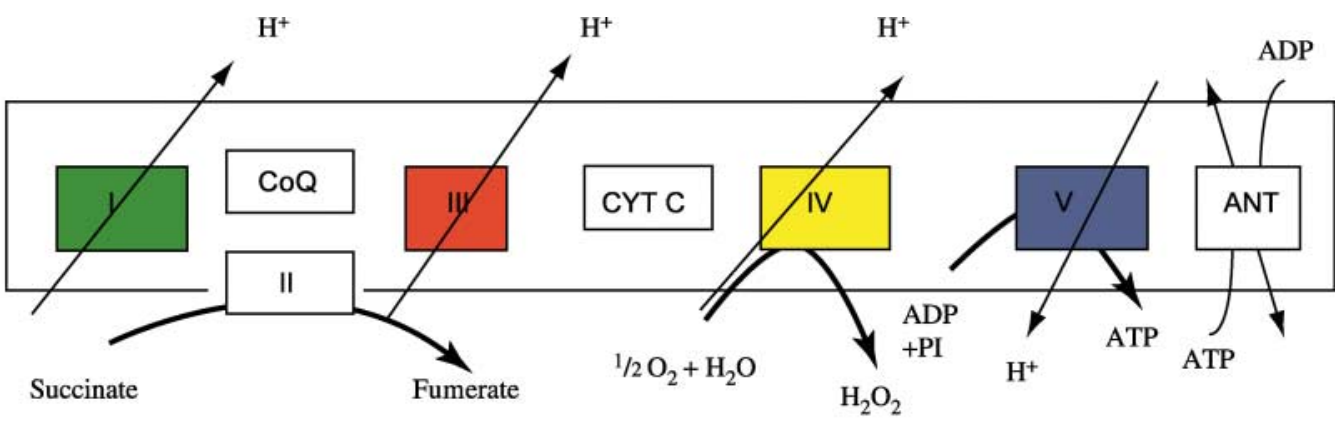

$\begin{array}{lrrccr}\text { Complex } & \text { I } & \text { II } & \text { III } & \text { IV } & \text { V } \\ \text { nDNA subunits } & >18 & 4 & 8 & 10 & 10 \\ \text { mtDNA subunits } & 7 & 0 & 1 & 3 & 2\end{array}$

Figure 1 The electron transfer chain (ETC). The ETC is a major component of OXPHOS, the main ATP generating pathway in the cell. Almost all protein subunits of the ETC (complex I, NADH dehydrogenase; complex III, ubiquinol:cytochrome c; complex IV, cytochrome c oxidase (COX); complex V, ATP synthase) contain mtDNA encoded subunits. There is one exception, complex II (succinate:ubiquinone oxidoreductase) which is entirely nuclear encoded.

which unlike any other cellular pathway is encoded for by two distinct genomes, the nuclear (nDNA) and mitochondrial (mtDNA) genomes. Mammalian mtDNA encodes 13 of the polypeptides that constitute part of the ETC (Anderson et al. 1981; see Fig. 2). It further consists of 22 transfer RNAs (tRNAs) and 2 ribosomal RNAs (rRNAs) thus making it a semi-autonomous molecular entity that requires interaction with the nucleus to instigate transcription and replication (see Clayton 1998).

\section{MtDNA homoplasmy and heteroplasmy - the clinical phenomenon}

The state of homoplasmy exists when all copies of mtDNA within a cell or tissue are identical either as wild type (WT) or mutant or deleted/rearranged. A mixing of two variants or the existence of WT and rearranged molecules results in heteroplasmy. The phenotypic onset of mtDNAtype disease is often dependent on the ratio of mutant:WT. Patient studies have indicated that in Leber's hereditary optic neuropathy (LHON) for example, $>60 \%$ mutant mtDNA load is required before the characteristic phenotype is observed (Chinnery et al. 2001). Other studies have indicated that a critical threshold level exists where over $85-90 \%$ of mutant mtDNAs must be present for a biochemical or clinical disease phenotype to be expressed (Boulet et al. 1992). Amongst the maternally inherited point mutations, there are: mutations in individual rRNA/tRNA complexes associated with mitochondrial myopathy, encephalopathy, lactic acidosis and stroke-like episodes (MELAS; Goto et al. 1990); myoclonic epilepsy and ragged-red fibre disease (MERRF, Shoffner et al. 1990) and deafness (Torroni et al. 1999); mutations in the coding region, e.g. neurogenic weakness, ataxia, retinitis pigmentosa (NARP; Fryer et al. 1994); mitochondrial encephalomyopathy (Clark et al. 1999), and LHON (Wallace et al. 1988, Howell et al. 1991); and a combination of mitochondrial disease symptoms resulting from a point mutation at nucleotide 8993 (Holt et al. 1990). Mutations can also be transmitted in Mendelian fashion, e.g. chronic progressive external opthalmoplegia (CPEO; Cormier et al. 1991). This group arises from mutations in nuclear encoded components vital to mtDNA transcription and replication. This includes adenine nucleotide translocator (ANT) 1, an ADP/ATP translocator (Kaukonen et al. 2000), thymidine kinase 2 (Saada et al. 2001) and the mitochondrial deoxyguanosine kinase (Mandel et al. 2001) - both enzymes that are involved in a scavenger pathway that provides dNTPs for mtDNA replication, and polymerase gamma (PolG), the DNA polymerase specific to mtDNA (Van Goethem et al. 2001). In addition, mitochondrial transcription factor A (TFAM) is a vital transcription factor that binds to the D-loop, or control region, of the mitochondrial genome and regulates transcription and replication. Decreased TFAM expression has been associated with mtDNA depletion syndrome (TFAM; Poulton et al. 1994). Finally, large-scale deletions are harboured as sporadic single deletions or as an insertion-duplication of mtDNA, which can act as an intermediate, as for example in Kearns-Sayre syndrome (KSS; Schon et al. 1989), and is often characterised by the $4977 \mathrm{bp}$ 'common' deletion. Multiple large-scale deletions are also observed in postmitotic tissues such as muscle (Holt et al. 1988), and can be induced through ageing mechanisms such as the generation of free radicals (Hayakawa et al. 1995). 


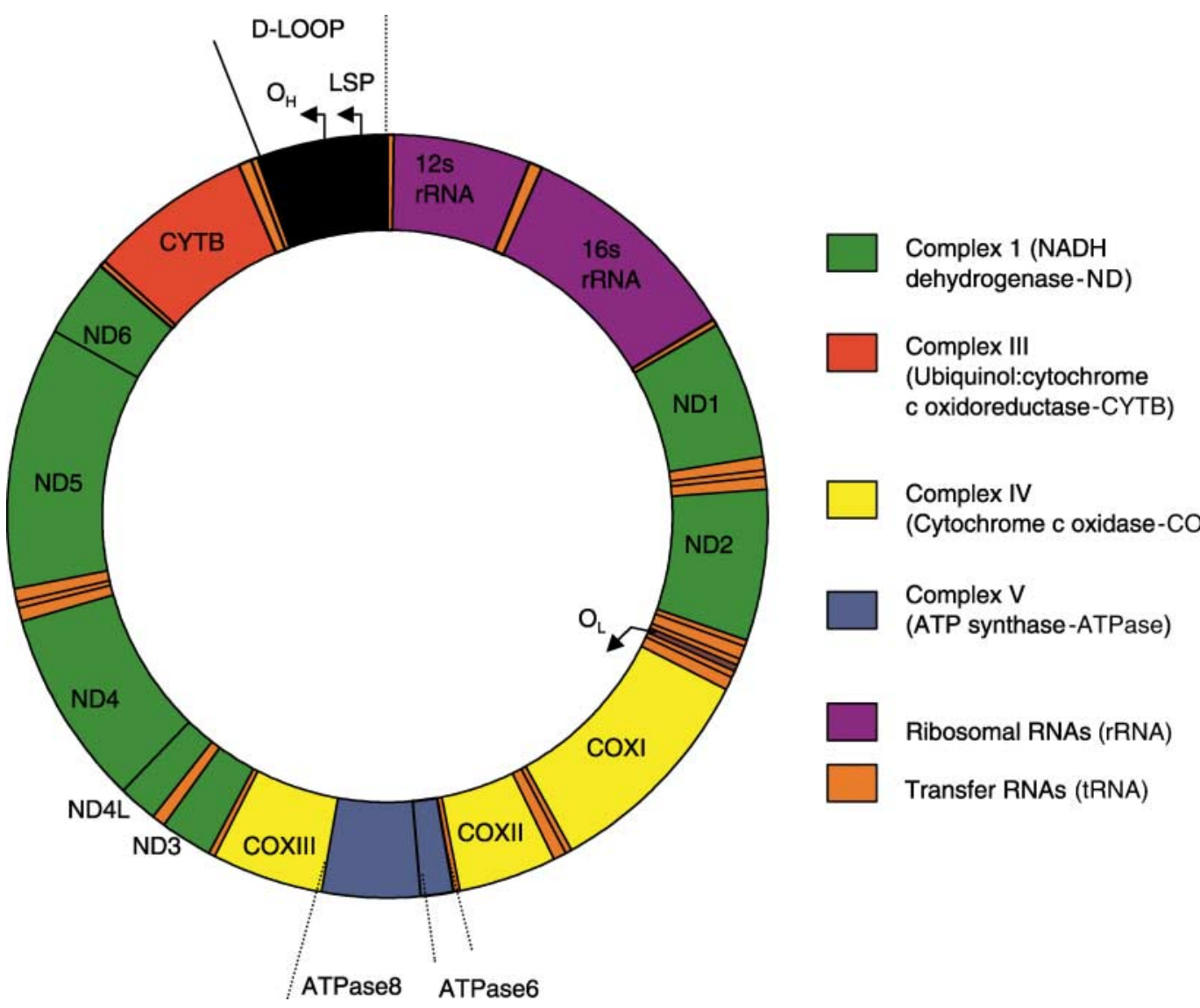

Figure 2 Mammalian mtDNA. Mammalian mtDNA is a double stranded molecule, composed of a $\mathrm{H}$ (heavy) strand and a $\mathrm{L}$ (light) strand and is approximately $16.5 \mathrm{~kb}$ in size (e.g. human mtDNA is $16.569 \mathrm{~kb}$; Anderson et al. 1981). The origin for $\mathrm{H}$-strand replication $\left(\mathrm{O}_{\mathrm{H}}\right)$ and the HSP and LSP transcription promoters are located in the D-loop (displacement loop). The origin for L-strand replication $\left(\mathrm{O}_{\mathrm{L}}\right)$ is located two thirds away around the genome from the D-loop. MtDNA encodes thirteen proteins of the electron transport chain (ETC). Twelve genes are located on the $\mathrm{H}$-strand and only one gene is located on the L-strand. mtDNA also has 22 tRNAs and 2 rRNAs involved in mtDNA transcript production and processing.

\section{Heteroplasmy derived from the coexistence of two distinct alleles}

The coexistence of two or more mtDNA alleles, defined as sequence variants, can result from sperm transmission from interspecific crossings or from supplementation arising through cytoplasmic transfer or nuclear transfer. These techniques contravene the strict mechanism that regulates mtDNA transmission post-fertilisation. mtDNA is primarily transmitted through the oocyte and consequently is maternally inherited (Birky 1995, 2001). This is perhaps best demonstrated in intraspecific crossings of mice that appear to eliminate sperm mitochondria by the late pronuclear stage (Kaneda et al. 1995, Shitara et al. 2001), and before the 8-cell stage in cattle and the rhesus macaque (Sutovsky et al. 1999). This process is thought to be mediated through the labelling of mitochondria in the spermatogonia by ubiquitin resulting in their subsequent targeting by oocyte-driven ubiquitination (Sutovsky et al. 1999). Interspecific crosses behave differently by ignoring this ubiquitin-mediated event and allowing sperm mtDNA to be transmitted, albeit at low levels, to the resultant offspring (Gyllensten et al. 1991, Shitara et al. 1998). However, this molecule is not transmitted to subsequent generations (Shitara et al. 1998). Interestingly, biparental transmission has also been observed in Drosophila and mussels (Fisher \& Skibinski 1990, Hoeh et al. 1991), with male mussel offspring harbouring both maternaland paternal-type genomes and female offspring having maternal-only genomes. Until recently, it was understood that humans transmitted mtDNA in a strictly maternal mode (Giles et al. 1980, Shitara et al. 1998, Korpelainen 1999). However, paternal mtDNA can persist in a few polyploidy embryos generated through IVF (St John et al. 2000), and this persistence in blastocysts can account for the mtDNA myopathy observed in a male patient (Schwartz \& Vissing 2002). Other evidence exists to suggest that sperm mtDNA can persist, but again in an infrequent manner, following spermatid injection (Cummins et al. 1998). 
Cytoplasmic transfer (CT) is a relatively new assisted reproduction technique. It involves the injection of donor cytoplasm as well as a sperm in order to supplement the defective cytoplasm of those oocytes from patients with repeated embryonic development failure (Cohen et al. 1997). This may arise as the mitochondria present in the mature oocyte at fertilisation provide the energy needed by the embryo for the entire preimplantation phase of development, as there is no replenishment of mitochondria until the post-blastocyst stage (Piko \& Taylor 1987, Larsson et al. 1998). It has been shown that there is a critical number of mitochondria, approximately 100000 , that must be present in the unfertilised oocyte to allow embryo development after fertilisation in the human (Van Blerkom et al. 1998, Reynier et al. 2001, Hsieh et al. 2002). This number may be essential because a threshold level of ATP is required for cell division (Brenner et al. 2000), or a certain number of mitochondria may be required to synchronise the cellular dynamics, essential for early embryonic development. CT has been reasonably successful, showing higher than expected pregnancy rates in women unable to conceive via other methods (Cohen et al. 1997, 1998), particularly older women with poor quality oocytes (Barritt et al. 2001a). However, this technology results in some of the offspring possessing two cytoplasmic parents (St John \& Barratt 1997, Brenner et al. 2000, St John 2002) as well as two chromosomal parents (sperm and oocyte chromosomal DNA). It can further result in spontaneous or selective abortion arising from Turner's syndrome $(46, \mathrm{X} 0)$ and the onset of pervasive development disorder (Barritt et al. 2001b). Mouse studies have substantiated that foreign mtDNA injected into either the oocyte or the zygote can be transmitted in varying amounts, for example $5-80 \%$ (Laipis 1996), $0-30 \%$ (Jenuth et al. 1996) and 16-100\% (Meirelles \& Smith 1997), suggesting that those molecules introduced can be transmitted at random frequency.

A state of heteroplasmy can also result following NT where transmission of mtDNA as well as nuclear DNA from the donor cell may occur (Gaertig et al. 1988), as there are several thousand mtDNA genomes in most somatic cells (Michaels et al. 1982). Patterns of mtDNA inheritance are inconsistent in offspring generated through NT as the process bypasses the normal uniparental mechanisms of mtDNA inheritance. Consequently, NT offspring will exhibit one of three patterns of mtDNA transmission namely, homoplasmy derived solely from the recipient oocytes, homoplasmy derived exclusively from the donor somatic cell, or heteroplasmy resulting from the fusion partners.

Both homoplasmy (Evans et al. 1999) and varying degrees of heteroplasmy (Steinborn et al. 1998a, $b$; Heindleder et al. 1999, Takeda et al. 1999, Meirelles et al. 2001, Steinborn et al. 2002) have been observed. Homoplasmy may have resulted from a failure by donor mitochondria to enter the ooplasm following electrofusion (Evans et al. 1999). Alternatively, donor mitochondria could be actively destroyed by a mechanism similar to the ubiquitination of sperm mitochondria, as demonstrated in intraspecific crossings following natural conception or IVF (Ankel-Simons \& Cummins 1996, Sutovsky et al. 1999). The existence of heteroplasmy shows that in contrast to the exclusion of sperm mtDNA following sexual inheritance, cloning can result in the mixing and the co-existence of parental mtDNAs. Donor mtDNA has been found to make up between 0 and $59 \%$ of the total cell mtDNA in those tissues analysed (see Table 1). The use of embryonic cells at different stages of development may result in less donor mtDNA being introduced into the newly reconstructed oocytes (Steinborn et al. 1998b). However, there is considerable variability between disassociated blastomeres which could account for variable levels of transmission (Van Blerkom et al. 2000). Most interesting, however, is the recent study of mtDNA in NT calves which clearly demonstrates a replicative advantage of donor mtDNA over the recipient oocytes mtDNA (Takeda et al. 2003), although it is important to note the differences in mtDNA composition between tissues of the same cloned individual (see Table 1). This is in contrast to another report where no advantage was observed for donor mtDNA (Hiendleder et al. 2003). These variations in reported mtDNA composition could be related to differences in the NT procedure or differences in nucleo-cytoplasmic interactions. The proportion of donor mtDNAs present may be related to the quantity of donor cell cytoplasm present post reconstruction (Takeda et al. 2003). This is perhaps best exemplified by those protocols that actively destroy the donor cell cytoplasm prior to its injection into the recipient oocyte's cytoplasm (Wakayama \& Yanagimachi 2001).

\section{How is mtDNA transmission regulated following non-invasive assisted reproduction?}

Primordial follicles contain as few as 10 mitochondria (Jansen \& de Boer 1998) and the mtDNA molecules within them are clonally amplified (Marchington et al. 1997) from oogenesis up until complete maturation at metaphase II (Smith \& Alcivar 1993). This clonal expansion results in more than 100000 copies being present in those oocytes deemed capable of fertilisation and maintaining embryonic development (Reynier et al. 2001). The restriction to a few mtDNA copies present at the primordial follicle stage results in a genetic bottleneck (Hauswirth \& Laipis 1982, Poulton 1995). This genetic bottleneck event is thought to be proceeded by random genetic drift (Jenuth et al. 1996) and/or non-directed segregation promoting the homoplasmic transmission of mtDNA, whenever feasible. Either of these processes would explain the vast difference in mutant load observed in a series of oocytes from one ovarian source - 0 to $95 \%$ - due to unequal levels of mtDNA present in individual segregating blastomeres (Blok et al. 1997). 
Table 1 Representative examples of levels of heteroplasmy detected in mammals derived from nuclear transfer. Both homoplasmy and varying degrees of heteroplasmy have been detected in mammals produced by NT. Clear differences also exist in donor mtDNA levels between tissues and at different stages in development.

\begin{tabular}{|c|c|c|c|}
\hline Offspring analysed & Donor cell & Degrees of heteroplamsy observed (\% donor mtDNA) & Reference \\
\hline 10 live sheep clones & Somatic & $\begin{array}{l}\text { Homoplasmic for the recipient in all tissues analysed } \\
\text { (blood, skeletal muscle, placenta and skin) } \\
\text { for all sheep }\end{array}$ & Evans et al. (1999) \\
\hline 4 live cattle clones & Embryonic & $\begin{array}{l}13 \text { and } 18 \% \text { in } 2 \text { clones derived from } 24 \text {-cell morulae } \\
0.6 \text { and } 0.4 \% \text { in } 2 \text { clones derived from } 92 \text {-cell morulae }\end{array}$ & Steinborn et al. (1998b) \\
\hline 29 individuals of 7 cattle clones & Embryonic & $21-57 \%$ in 2 of the clones $2-4 \%$ in others & Hiendleder et al. (1999) \\
\hline $\begin{array}{l}11 \text { live cattle clones } \\
\text { (subspecies crosses, } \\
\text { B. indicus and B. taurus) }\end{array}$ & Somatic & $\begin{array}{l}0-28 \% \text { (blood, muscle, skin, oocytes, follicular cells) } \\
\text { Co-existence of } B . \text { taurus and } B \text {. indicus }\end{array}$ & Steinborn et al. (2002) \\
\hline 80 12-day bovine fetuses & Somatic & $\begin{array}{l}\text { Blood } 0-5 \% \\
\text { Homoplasmic for the recipient in all other tissues analysed } \\
\text { (skin, muscle, brain, lung, heart, rumen, jejenum, liver, } \\
\text { spleen, kidney, cotyledon) }\end{array}$ & Hiendleder et al. (2003) \\
\hline $\begin{array}{l}16 \text { embryos immediately after } \\
\text { electrofusion }\end{array}$ & Somatic & $\begin{array}{l}3 \text { of } 16 \text { embryos showed low levels of donor mtDNA ( } 3-4 \% \text { ) } \\
\text { immediately after fusion }\end{array}$ & Takeda et al. (2003) \\
\hline 11 NT calves and foetuses & Somatic & $\begin{array}{l}3 \text { of } 11 \text { NT calves/fetuses exhibited heteroplasmy. } \\
\text { (C1: } 25-51 \%, \text { C2: } 0-15 \%, \text { C } 3: 8-59 \%) \\
\text { Differences between tissues were observed. }\end{array}$ & Takeda et al. (2003) \\
\hline
\end{tabular}

C1, C2 and C3 are individual clones 1, 2 and 3.

\section{Consequences resulting from the transmission of two genomes - competitiveness of one genome over another}

Both CT and NT bypass this early genetic restriction event resulting in heteroplasmic distribution across many tissue types and to future generations (Hiendleder et al. 2003). However, of considerable relevance is that replication of mtDNA does not occur until the hatched blastocyst stage of development (Piko \& Taylor 1987). Before this stage, each mitochondrion and its copy of mtDNA will be transferred to just one blastomere. This segregation continues as the blastomeres divide. Mouse studies have shown that foreign mtDNA injected into the karyoplast tends to be spread equally throughout the daughter blastomeres, whereas the mitochondria injected into the cytoplast segregate preferentially to one daughter cell or another (Meirelles \& Smith 1998). This is probably due to the mtDNA injected into the karyoplast being close to the nuclear genetic material, which is always divided equally among daughter blastomeres. It has been suggested that mtDNA within specific regions of a cell is preferentially replicated (Davis \& Clayton 1996). However, a recent study suggests that perceived preferential replication only arises due to the higher numbers of mitochondria surrounding the nucleus, and is not due to favourable locations for mtDNA replication. To this extent, it has been demonstrated that mtDNA replication takes place throughout the cell cytoplasm in various human somatic cells (Magnusson et al. 2003). The position of mitochondria within an oocyte certainly plays an important role in determining where they will be located within the developing embryo and offspring (Meirelles \& Smith 1998). This may therefore be due to either preferential replication or simply segregation during cell division. In any case, this could be of considerable importance in deciding where to inject supplementary mitochondria during cytoplasmic transfer.

It has been suggested that some progeny produced by NT show preferential replication of nuclear donor mtDNA (Do et al. 2002), perhaps due to the presence of compatible nuclear factors, for example TFAM. Those studies testing the proportion of different mtDNA genotypes after NT and CT have produced varying results both within and between individuals. These range from complete homoplasmy to equal proportions of two or more genotypes. The range of heteroplasmic states reported so far may be due to a number of factors such as nucleo-cytoplasmic incompatibility. The ideal outcome for CT would be the supplementation of oocytes with mtDNA from the same genotype (St John 2002).

\section{Use of cybrid technology as a means of evaluating nucleo-cytoplasmic interactions}

Cybrids, or cytoplasmic hybrids, have been used to study nucleo-cytoplasmic interactions in humans (King \& Attardi 1988, 1989). More recently, the fate of mtDNA populations against different nuclear backgrounds have been analysed (Dunbar et al. 1995, Barrientos et al. 1998, 2000, Moraes et al. 1999, Dey et al. 2000, McKenzie \& Trounce 2000, McKenzie et al. 2003). Typically, a homoplasmic cybrid is formed by the fusion of an enucleated cell (cytoplast) with an mtDNA-depleted cell possessing a somatic nucleus (karyoplast). Heteroplasmic cybrids can be generated through either the fusion of a heteroplasmic cytoplast, containing for example a mixture of mutant mtDNA and WT mtDNA, with a mtDNA-depleted cell (Dunbar et al. 1995, Inoue et al. 2000), or the fusion of a 


\begin{tabular}{|c|c|c|c|c|c|c|c|}
\hline $\begin{array}{l}\text { Cybrid (nuclear } \\
\text { background-cytoplast) }\end{array}$ & $\begin{array}{l}\text { Homoplasmic/ } \\
\text { heteroplasmic }\end{array}$ & OXPHOS & $\begin{array}{l}\text { Respiratory } \\
\text { complex activity }\end{array}$ & Oxygen consumption & $\begin{array}{l}\text { Mitochondrial } \\
\text { protein synthesis }\end{array}$ & $\begin{array}{l}\text { mtDNA replication } \\
\text { and transcription }\end{array}$ & $\begin{array}{l}\text { Lactate } \\
\text { (indicates the } \\
\text { level of } \\
\text { ATP production) }\end{array}$ \\
\hline $\begin{array}{l}\text { Murine-murine (Dey } \\
\text { et al. 2000, McKenzie \& } \\
\text { Trounce 2000, McKenzie } \\
\text { et al. 2003) }\end{array}$ & $\begin{array}{l}\text { Homoplasmic } \\
\text { for murine } \\
\text { mtDNA }\end{array}$ & $\begin{array}{l}\text { Unaffected (Dey } \\
\text { et al. 2000, } \\
\text { McKenzie \& } \\
\text { Trounce 2000, } \\
\text { McKenzie et al. } \\
\text { 2003) }\end{array}$ & $\begin{array}{l}\text { Unaffected (Dey et al. } \\
\text { 2000, McKenzie \& } \\
\text { Trounce 2000, McKenzie } \\
\text { et al. 2003) }\end{array}$ & $\begin{array}{l}\text { Unaffected (Dey et al. } \\
\text { 2000) }\end{array}$ & $\begin{array}{l}\text { Unaffected (Dey et al. } \\
\text { 2000, McKenzie \& } \\
\text { Trounce 2000) }\end{array}$ & $\begin{array}{l}\text { The replication of murine } \\
\text { mtDNA was unaffected } \\
\text { (Dey et al. 2000, } \\
\text { McKenzie \& Trounce } \\
\text { 2000, McKenzie et al. } \\
\text { 2003) }\end{array}$ & $\begin{array}{l}\text { Unaffected } \\
\text { (McKenzie et al. } \\
\text { 2003) }\end{array}$ \\
\hline $\begin{array}{l}\text { Murine-rat (Dey et al. } \\
\text { 2000, McKenzie \& } \\
\text { Trounce 2000, McKenzie } \\
\text { et al. 2003) }\end{array}$ & $\begin{array}{l}\text { Homoplasmic } \\
\text { for rat mtDNA }\end{array}$ & $\begin{array}{l}\text { Compromised } \\
\text { (Dey et al. 2000, } \\
\text { McKenzie \& } \\
\text { Trounce 2000, } \\
\text { McKenzie et al. } \\
\text { 2003) }\end{array}$ & $\begin{array}{l}\text { Complex I and IV activity } \\
\text { was } 50 \% \text { lower in } \\
\text { murine-rat cybrids } \\
\text { compared with parental } \\
\text { cell lines and murine- } \\
\text { murine cybrids (Dey et al. } \\
2000 \text { ). Complex I, III and } \\
\text { IV activities were reduced } \\
\text { to } 46 \%, 37 \% \text { and } 78 \% \\
\text { that of the murine-murine } \\
\text { cybrids (McKenzie \& } \\
\text { Trounce } 2000 \text { ) }\end{array}$ & $\begin{array}{l}50 \% \text { lower in murine- } \\
\text { rat cybrids compared } \\
\text { with parental cell lines } \\
\text { and murine-murine } \\
\text { cybrids (Dey et al. 2000) }\end{array}$ & $\begin{array}{l}\text { Unaffected (Dey et al. } \\
\text { 2000, McKenzie \& } \\
\text { Trounce 2000) }\end{array}$ & $\begin{array}{l}\text { Rat mtDNA was replicated } \\
\text { efficiently (McKenzie \& } \\
\text { Trounce 2000) }\end{array}$ & $\begin{array}{l}\text { Increased cellular } \\
\text { production of } \\
\text { lactate (decreased } \\
\text { ATP production) } \\
\text { (McKenzie et al. } \\
\text { 2003) }\end{array}$ \\
\hline $\begin{array}{l}\text { Murine-rat (Dey et al. } \\
\text { 2000) }\end{array}$ & $\begin{array}{l}\text { Heteroplasmic } \\
\text { harbouring } \\
\text { murine and rat } \\
\text { mtDNA }\end{array}$ & $\begin{array}{l}\text { Restored to levels } \\
\text { similar to those of } \\
\text { murine-murine } \\
\text { cybrids (Dey et al. } \\
\text { 2000) }\end{array}$ & & & & $\begin{array}{l}\text { A shift in murine mtDNA } \\
\text { levels was observed } \\
\text { following } 12 \text { weeks of } \\
\text { culture from } 1.5 \text { to } 10 \% \\
\text { that was sufficient to } \\
\text { restore respiration (Dey } \\
\text { et al. 2000) }\end{array}$ & \\
\hline $\begin{array}{l}\text { Murine-murine } \\
\text { harbouring mutant } \\
\text { mtDNA (Inoue et al. 2000) }\end{array}$ & Homoplasmic & $\begin{array}{l}\text { Compromised in } \\
\text { cybrids with a } \\
\text { predominance of } \\
\text { mutant mtDNA }\end{array}$ & COX activity reduced & & $\begin{array}{l}\text { Mitochondrial } \\
\text { translation was reduced }\end{array}$ & $\begin{array}{l}\text { Prolonged culture of one } \\
\text { cybrid resulted in a shift } \\
\text { from } 30 \% \text { to } 83 \% \text { mutant } \\
\text { mtDNA, but then } \\
\text { remained stable }\end{array}$ & \\
\hline $\begin{array}{l}\text { Human-non-human ape } \\
\text { (common chimp, pigmy } \\
\text { chimp and gorilla) cybrids } \\
\text { (Barrientos et al. 1998, } \\
\text { Moraes et al. 1999) }\end{array}$ & $\begin{array}{l}\text { Homoplasmic } \\
\text { for non- } \\
\text { human } \\
\text { mtDNA }\end{array}$ & $\begin{array}{l}\text { The activities of } \\
\text { complexes II, III, } \\
\text { IV and V were } \\
\text { unaltered } \\
\text { (Barrientos et al. } \\
\text { 1998) }\end{array}$ & $\begin{array}{l}\text { Complex I deficiency } \\
\text { (Barrientos et al. 1998) }\end{array}$ & & $\begin{array}{l}\text { The level of ND1, } \\
75 \mathrm{kDa} \text { and } 49 \mathrm{kDa} \\
\text { protein subunits of } \\
\text { complex I were } \\
\text { unaltered (Barrientos } \\
\text { et al. 1998) }\end{array}$ & $\begin{array}{l}\text { Human-non-human ape } \\
\text { cybrids survived in culture } \\
\text { under selection for } \\
\text { respiratory function } \\
\text { implying mtDNA from } \\
\text { non-human apes can } \\
\text { replicate and restore } \\
\text { respiration within a human } \\
\text { nuclear background } \\
\text { (Moraes et al.. 1999) }\end{array}$ & \\
\hline
\end{tabular}




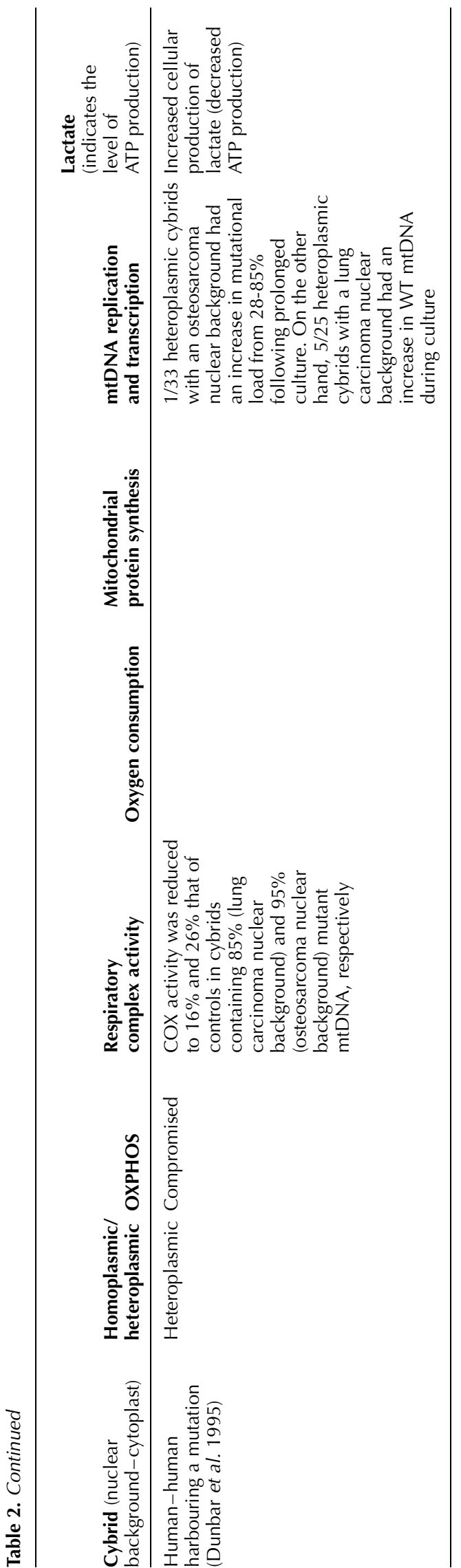

cytoplast with a cell containing mtDNA, producing a cybrid with donor and recipient mtDNA (Moraes et al. 1999, Dey et al. 2000). Cybrid technology has also been used to analyse the transmission of mtDNA to offspring by introducing mtDNA into one-cell embryos (Inoue et al. 2000) and also into blastocysts (Sligh et al. 2000). Table 2 clearly highlights the variation in mtDNA replication and transcription that can arise through nucleo-cytoplasmic variation. Of specific interest are the results arising from interspecies cybrid generation where rat mtDNA is efficiently replicated, transcribed, and translated against a murine nuclear background, although OXPHOS function is compromised, which compares unfavourably with murine-murine cybrids (Dey et al. 2000, McKenzie \& Trounce 2000, McKenzie et al. 2003). This is further exemplified as primate mtDNA is only replicated when the human cell's own mtDNA has been eliminated (Moraes et al. 1999). The anticipated problems include the variable mtDNA sequences between two populations that could result in amino acid incompatability and a dysfunctional ETC with decreased levels of ATP. Such an outcome would be similar to those human phenotypes associated with mtDNA depletion syndromes (Larsson et al. 1994, Poulton et al. 1994) arising from decreased levels of TFAM expression reducing mtDNA copy number. Indeed, mtDNA mutations, which are characteristic of mtDNA depletion, result in phenotypic changes in animals including growth and milk quality in Holstein cows (Schutz et al. 1994, Nagao et al. 1998). These outcomes certainly necessitate the importance of establishing nucleo-cytoplasmic compatibility before attempting NT and CT. This is especially so following the recent report of human embryonic stem cells (hESCs) being derived by autologous SCNT (Hwang et al. 2004). Consequently, human-human cybrids would provide an excellent model for studying the diversity of a distinctive somatic nucleus against that of an embryonic genome. This would also provide a valuable insight into the compatibility of the nucleus from one cell type with that of the cytoplasmic background from another individual. Such investigations would clearly determine nucleo-cytoplasmic efficiencies related to ESC derivation.

\section{Could upstream epigenetic errors impact on mitochondria numbers in cells and respective copies of mtDNA per mitochondrion?}

Somatic cell NT utilises a differentiated cell as its source of chromosomal DNA, which requires reprogramming prior to the first cell division. The genotype of a series of cells from an individual organism is identical, but cellspecific gene expression results in an individual cell's identity related to function and morphology (Shi et al. 2003). Consequently, these donor nuclei should be reprogrammed to adopt the characteristics of a newly fertilised zygote that has either commenced or completed 
recombination of the male and female pronuclei. The naturally or in vitro fertilised oocyte undergoes a series of epigenetic events (Reik \& Dean 2003). These include methylation and deacetylation, regulators of imprinting, which are key to developmental events. However, evidence from studies related to IVF and intra cytoplasmic sperm injection (ICSI) has shown that correct imprinting patterns are essential to normal development. Consequently, Beckwith Wiedemann syndrome, an imprinting disorder, has been reported in more severe instances following assisted reproduction (Maher et al. 2003). More importantly, imprinting disorders can be phenotypically lethal (see Lee et al. 2002). In addition, other key markers of early differentiation, such as certain pluripotent genes, are expressed during normal embryo development although they are not necessarily present in somatic cloned embryos nor beforehand in their contributing somatic nucleus (Boiani et al. 2002, Bortvin et al. 2003). The most-studied is Oct-4 and associated family members, including Dppa1, Pramel4, Pramel5 and Pramel6 (Bortvin et al. 2003).

We hypothesise that failure of somatic donor nuclei to express key markers of an unprogrammed nucleus indicates that aberrant gene expression or silencing compromises early embryonic development that will deviate markedly from the expected pattern. This will perhaps best be identified in the failure of the highly regulated nucleo-cytoplasmic interaction. Consequently, the nucleus which regulates mtDNA transcription and replication through its expression of specific transcription factors, for example TFAM, may result in subsequent blastomeres adopting the phenotype of the nuclear donor cell type, resulting in the inner mass cells and those contributing to the foetus phenotypically expressing mitochondrial morphology and mtDNA copy number of that particular cell type. This would influence mitochondrial morphology, mtDNA copy number, and the number of mitochondria per cell and thus OXPHOS capacity for organs or tissues. This is particularly critical as the number of mitochondria and the mtDNA copy number are unique to each cell type and related to OXPHOS requirement, as predicted for individual post-mitotic cell types (see Moyes et al. 1998).

Multiple copies of the mtDNA genome are found in individual mitochondria in somatic cells although only a single copy is found in those of the oocyte (Jansen \& de Boer 1998). The degree of multiple copies is hypothesised to be regulated by the ATP requirement of individual cells (Moyes et al. 1998). For example, in rat tissue the mean number of mtDNA copies per mitochondrion for the ventricle is 0.7 , for liver 2.7, for red muscle 0.9 and for white muscle 1.9. Furthermore, the mtDNA copy numbers per cell type have been demonstrated to be significantly different between cell types. For example, in skeletal and cardiac muscle there are $3650 \pm 620$ and $6790 \pm 920$ mtDNA copies per diploid nuclear genome respectively, representing a significant difference of $P=0.006$ (Miller et al. 2003). The mtDNA copy number in peripheral blood mononuclear cells is $409 \pm 148$ copies per cell and in subcutaneous fat it is $2049 \pm 391$ (Gahan et al. 2001), whilst cultured fibroblasts possess $823 \pm 71$ copies/cell (Zhang et al. 1994). Interestingly, there are $2.6 \times 10^{5}$ copies per bovine oocyte whilst bovine fetal heart fibroblasts possess $2.6 \times 10^{3}$ copies/cell (Michaels et al. 1982). Considerable variation has also been demonstrated in rat tissues, with ventricle tissue possessing $279 \times 10^{9} \mathrm{mtDNA}$ copies per gram tissue, liver $743 \times 10^{9}$, red muscle $230 \times 10^{9}$, and white muscle $116 \times 10^{9}$ (Wiesner et al. 1992). Failure of the nucleus to be fully reprogrammed can result in failure of appropriate mtDNA segregation during embryogenesis and can affect ATP production and cellular development. A mechanism for regulating such outcomes during early embryo development would be to analyse the differences between mtDNA transcription and replication of CT- and NT-generated embryos and the distribution of the heteroplasmic genomes to individual blastomeres. Consequently, the outcomes of mtDNA supplementation are being tested under the regulation of the embryonic and somatic nuclear genomes throughout early embryogenesis.

To further support our hypothesis, analysis of the initiation of mtDNA transcription and replication post fertilisation provides key evidence. mtDNA transcription and replication is mediated by nuclear-encoded transcription factors that are imported into the mitochondria (Clayton 1998). Transcription proceeds from the 2-cell stage in the developing murine embryo although mtDNA copy number is constant until the blastocyst stage (Piko \& Taylor 1987). MtDNA copy number is probably maintained by nuclear respiratory factor (NRF)-1, where homozygous null mice survive up to embryonic day (E) 6.5 (Hou \& Scarpulla 2001). However, there is continual dilution of the mtDNA genome to each newly generated blastomere until replication is initiated post-implantation. One of the major regulators of this event is TFAM. In those homozygous murine TFAM knockout embryos, severe mtDNA depletion is observed with embryo survival persisting as far as E10.5. This is in contrast with heterozygous offspring that phenotypically present with cardiomyapthy, a severe debilitating mtDNA disorder (Larsson et al. 1998).

\section{Conclusion}

It is evident that nucleo-cytoplasmic interaction is vital to the successful generation of live offspring. Whilst epigenetic factors related to imprinting can result in earlier onset syndromes, it is imperative that full investigations are conducted on the genetic compatibility of the nucleus and the mitochondrion to fully initiate an appropriate level of differentiation in order that the cytoplasm can effectively generate appropriate levels of ATP. The consequence of reduced ATP levels would promote mtDNA-depletion syndromes as evidenced in certain clinical conditions categorised in the human. Furthermore, a cytoplasm over-populated with mitochondria would lead 
to cellular expansion that might be indicative of the reported large-offspring syndromes. This under-researched area of investigation could provide clear answers to some of the developmental abnormalities witnessed in NT offspring and aborted foetuses, whether mediated through failure of somatic cell reprogramming or independently.

\section{References}

Anderson S, Bankier AT, Barrell BG, de Bruijn MH, Coulson AR, Drouin J, Eperon IC, Nierlich DP, Roe BA \& Sanger F 1981 Sequence and organization of the human mitochondrial genome. Nature 290 457-465.

Ankel-Simons F \& Cummins JM 1996 Misconceptions about mitochondria and mammalian fertilisation: implications for theories on human evolution. PNAS 9313859-9313863.

Barrientos A, Kenyon L \& Moraes CT 1998 Human xenomitochondrial cybrids. Cellular models of mitochondrial complex I deficiency. Journal of Biological Chemistry 273 14210-14217.

Barrientos A, Muller S, Dey R, Wienberg J \& Moraes CT 2000 Cytochrome c oxidase assembly in primates is sensitive to small evolutionary variations in amino acid sequence. Molecular Biology and Evolution 17 1508-1519.

Barritt J, Brenner C, Malter H \& Cohen J 2001a Mitochondria in human offspring derived from ooplasmic transplantation. Human Reproduction 16 513-516.

Barritt J, Brenner C, Malter H \& Cohen J 2001b Rebuttal: interooplasmic transfers in humans. Reproductive BioMedicine Online 3 47-48.

Birky CW Jr 1995 Uniparental inheritance of mitochondrial and chloroplast genes: mechanisms and evolution. PNAS 92 11331-11338.

Birky CW Jr 2001 The inheritance of genes in mitochondria and chloroplasts: laws, mechanisms, and models. Annual Review of Genetics 35 125-148.

Blok RB, Gook DA, Thorburn DR \& Dahl HH 1997 Skewed segregation of the mtDNA nt $8993(\mathrm{~T} \rightarrow \mathrm{G})$ mutation in human oocytes. American Journal of Human Genetics 60 1495-1501.

Boiani M, Eckardt S, Scholer HR \& McLaughlin KJ 2002 Oct4 distribution and level in mouse clones: consequences for pluripotency. Genes and Development 16 1209-1219.

Bortvin A, Eggan K, Skaletsky H, Akutsu H, Berry DL, Yanagimachi R, Page DC \& Jaenisch R 2003 Incomplete reactivation of Oct4related genes in mouse embryos cloned from somatic nuclei. Development $1301673-1680$.

Brenner CA, Barritt JA, Willadsen S \& Cohen J 2000 Mitochondrial DNA heteroplasmy after human ooplasmic transplantation. Fertility and Sterility $\mathbf{7 4}$ 573-578.

Boulet L, Karpati G \& Shoubridge EA 1992 Distribution and threshold expression of the tRNA (Lys) mutation in skeletal muscle of patients with myoclonic epilepsy and ragged red fibres (MERRF). American Journal of Human Genetics 51 1187-1200.

Campbell KH, McWhir J, Ritchie WA \& Wilmut I 1996 Sheep cloned by nuclear transfer from a cultured cell line. Nature 380 64-66.

Chinnery PF, Andrews RM, Turnbull DM \& Howell NN 2001 Leber hereditary optic neuropathy: does heteroplasmy influence the inheritance and expression of the G11778A mitochondrial DNA mutation? American Journal of Medical Genetics 98 235-243.

Cibelli JB, Campbell KH, Seidel GE, West MD \& Lanza RP 2002 The health profile of cloned animals. Nature Biotechnology 20 13-14.

Clark KM, Taylor RW, Johnson MA, Chinnery PF, ChrzanowskaLightowlers ZM, Andrews RM, Nelson IP, Wood NW, Lamont PJ, Hanna MG, Lightowlers RN \& Turnbull DM 1999 An mtDNA mutation in the initiation codon of the cytochrome $C$ oxidase subunit II gene results in lower levels of the protein and a mitochondrial encephalomyopathy. American Journal of Human Genetics 64 1330-1339.
Clayton DA 1998 Nuclear-mitochondrial intergenomic communication. Biofactors 7 203-205.

Cohen J, Scott R, Schimmel T, Levron J \& Willadsen S 1997 Birth of an infant after transfer of anucleate donor oocyte cytoplasm into recipient eggs. The Lancet 350 186-187.

Cohen J, Scott R, Alikani M, Schimmel T, Munne S, Levron J, Wu L, Brenner C, Warner C \& Willadsen S 1998 Ooplasmic transfer in mature human oocytes. Molecular Human Reproduction $\mathbf{4}$ 269-280.

Cormier V, Rotig A, Geny C, Cesaro P, Dufier JL \& Munnich A 1991 Autosomal dominant deletions of the mitochondrial genome in a case of progressive encephalomyopathy. American Journal of Human Genetics 48 643-648.

Cummins JM, Wakayama T \& Yanagimachi R 1998 Fate of microinjected spermatid mitochondria in the mouse oocyte and embryo. Zygote 6 213-222.

Davis AF \& Clayton DA 1996 In situ localization of mitochondrial DNA replication in intact mammalian cells. Journal of Cell Biology $135883-893$

Dey R, Barrientos A \& Moraes CT 2000 Functional constraints of nuclear-mitochondrial DNA interactions in xenomitochondrial rodent cell lines. Journal of Biological Chemistry 275 31520-31527.

Do JT, Lee JW, Lee BY, Kim SB, Ryoo ZY, Lee HT \& Chung KS 2002 Fate of donor mitochondrial DNA in cloned bovine embryos produced by microinjection of cumulus cells. Biology of Reproduction $67555-560$.

Dunbar DR, Moonie PA, Jacobs HT \& Holt IJ 1995 Different cellular backgrounds confer a marked advantage to either mutant or wild type mitochondrial genomes. PNAS 92 6562-6566.

Evans MJ, Gurer C, Loike JD, Wilmut I, Schnieke AE \& Schon EA 1999 Mitochondrial DNA genotypes in nuclear transfer-derived cloned sheep. Nature Genetics 23 90-93.

Fisher C \& Skibinski DOF 1990 Sex-biased mitochondrial DNA heteroplasmy in the marine mussel Mytilus. Proceedings of the Royal Society of London B Series 242 149-156.

Fryer A, Appleton R, Sweeney MG, Rosenbloom L \& Harding AE 1994 Mitochondrial DNA 8993 (NARP) mutation presenting with a heterogeneous phenotype including 'cerebral palsy'. Archives of the Disabled Child 71 419-422.

Gaertig J, Kiernowska M \& Iftode F 1988 Induction of cybrid strains of Tetrahymena thermophilia by electrofusion. Journal of Cell Science $89253-261$.

Gahan ME, Miller F, Lewin SR, Cherry CL, Hoy JF, Mijch A, Rosenfeldt F \& Wesselingh SL 2001 Quantification of mitochondrial DNA in peripheral blood mononuclear cells and subcutaneous fat using real-time polymerase chain reaction. Journal of Clinical Virology 22 241-247.

Giles RE, Blanc H, Cann HM \& Wallace DC 1980 Maternal inheritance of human mitochondrial DNA. PNAS 77 6715-6719.

Goto Y, Nonaka I \& Horai S 1990 A mutation in the tRNA(Leu) (UUR) gene associated with the MELAS subgroup of mitochondrial encephalomyopathies. Nature 348 651-653.

Gyllensten U, Wharton D, Josefsson A \& Wilson AC 1991 Paternal inheritance of mitochondrial DNA in mice. Nature 352 255-267.

Hauswirth WW \& Laipis PJ 1982 Mitochondrial DNA polymorphism in a maternal lineage of Holstein cows. PNAS 79 4686-4690.

Hayakawa M, Katsumata K, Yoneda M, Tanaka M, Sugiyama S \& Ozawa T 1995 Mitochondrial DNA minicircles, lacking replication origins, exist in the cardiac muscle of a young normal subject. Biochemical and Biophysical Research Communications 215 952-960.

Heindleder S, Schmutz SM, Erhardt G, Green RD \& Plante Y 1999 Transmitochondrial differences and varying levels of heteroplasmy in nuclear transfer cloned cattle. Molecular Reproduction and Development 54 24-31.

Hiendleder S, Zakhartchenko V, Wenigerkind H, Reichenbach HD, Bruggerhoff K, Prelle K, Brem G, Stojkovic M \& Wolf E 2003 
Heteroplasmy in bovine fetuses produced by intra- and inter-subspecific somatic cell nuclear transfer: neutral segregation of nuclear donor mitochondrial DNA in various tissues and evidence for recipient cow mitochondria in fetal blood. Biology of Reproduction 68 159-166.

Hoeh WM, Blakley KH \& Brown WM 1991 Heteroplasmy suggests limited biparental inheritance of Mytlius mitochondrial DNA. Science 251 1488-1490.

Holt IJ, Harding AE \& Morgan-Hughes JA 1988 Deletions of muscle mitochondrial DNA in patients with mitochondrial myopathies. Nature 25 717-719.

Holt IJ, Harding AE, Petty RK \& Morgan-Hughes JA 1990 A new mitochondrial disease associated with mitochondrial DNA heteroplasmy. American Journal of Human Genetics 46 428-433.

Howell N, Bindoff LA, McCullough DA, Kubacka I, Poulton J, Mack D, Taylor L \& Turnbull DM 1991 Leber hereditary optic neuropathy: identification of the same mitochondrial ND1 mutation in six pedigrees. American Journal of Human Genetics 49 939-950.

Hsieh RH, Tsai NM, Au HK, Chang SJ, Wei YH \& Tzeng CR 2002 Multiple rearrangements of mitochondrial DNA in unfertilised human oocytes. Fertility and Sterility 77 1012-1017.

Huo L \& Scarpulla RC 2001 Mitochondrial DNA instability and peri-implantation lethality associated with targeted disruption of nuclear respiratory factor 1 in mice. Molecular and Cellular Biology 21 644-654.

Hwang WS, Ryu YJ, Park JH, Park ES, Lee EG, Koo JM, Chun HY, Lee BJ, Kang SK, Kim SJ, Ahn C, Hwang JH, Park KY, Cibelli JB \& Moon Y 2004 Evidence of a pluripotent human embryonic stem cell line derived from a cloned blastocyst. Science 2004303 1669-1674.

Inoue K, Nakada K, Ogura A, Isobe K, Goto Y, Nonaka I \& Hayashi JI 2000 Generation of mice with mitochondrial dysfunction by introducing mouse mtDNA carrying a deletion into zygotes. Nature Genetics 26 176-181.

Jansen RP \& de Boer K 1998 The bottleneck: mitochondrial imperatives in oogenesis and ovarian follicular fate. Molecular and Cellular Endocrinology 145 81-88.

Jenuth JP, Peterson AC, Fu K \& Shoubridge EA 1996 Random genetic drift in the female germline explains the rapid segregation of mammalian mitochondrial DNA. Nature Genetics 14 146-151.

Kaneda H, Hayashi JI, Takahama S, Taya C, Lindahl KF \& Yonekawa H 1995 Elimination of paternal mitochondrial DNA in intraspecific crosses during early mouse embryogenesis. PNAS 92 4542-4546.

Kaukonen J, Juselius JK, Tiranti V, Kyttala A, Zeviani M, Comi GP, Keranen S, Peltonen L \& Suomalainen A 2000 Role of adenine nucleotide translocator 1 in mtDNA maintenance. Science 289 $782-785$

King MP \& Attardi G 1988 Injection of mitochondria into human cells leads to a rapid replacement of the endogenous mitochondrial DNA. Cell 52 811-819.

King MP \& Attardi G 1989 Human cells lacking mtDNA: repopulation with exogenous mitochondria by complementation. Science 246 500-503.

Korpelainen H 1999 Genetic maternal effects on human life span through the inheritance of mitochondrial DNA. Human Hereditary 49 183-185.

Laipis PJ 1996 Construction of heteroplasmic mice containing two mitochondrial DNA genotypes by micromanipulation of single-cell embryos. Methods in Enzymology 264 345-357.

Larsson NG, Oldfors A, Holme E \& Clayton DA 1994 Low levels of mitochondrial transcription factor $A$ in mitochondrial DNA depletion. Biochemical and Biophysical Research Communications 200 1374-1381.

Larsson NG, Wang J, Wilhelmsson H, Oldfors A, Rustin P, Lewandoski M, Barsh GS \& Clayton DA 1998 Mitochondrial transcription factor $A$ is necessary for mtDNA maintenance and embryogenesis in mice. Nature Genetics 18 231-236.

Lazzari G, Wrenzycki C, Herrmann D, Duchi R, Kruip T, Niemann H \& Galli C 2002 Cellular and molecular deviations in bovine in vitro-produced embryos are related to the large offspring syndrome. Biology of Reproduction 67 767-775.

Lee J, Inoue K, Ono R, Ogonuki N, Kohda T, Kaneko-Ishino T, Ogura A \& Ishino F 2002 Erasing genomic imprinting memory in mouse clone embryos produced from day 11.5 primordial germ cells. Development 129 1807-1817.

McKenzie M \& Trounce I 2000 Expression of Rattus norvegicus mtDNA in Mus musculus cells results in multiple respiratory chain defects. Journal of Biological Chemistry 275 31514-31519.

McKenzie M, Chiotis M, Pinkert CA \& Trounce IA 2003 Functional respiratory chain analyses in murid xenomitochondrial cybrids expose coevolutionary constraints of cytochrome $b$ and nuclear subunits of complex III. Molecular Biology and Evolution 20 1117-1124.

Magnusson J, Orth M, Lestienne P \& Taanman JW 2003 Replication of mitochondrial DNA occurs throughout the mitochondria of cultured human cells. Experimental Cell Research 289 133-142.

Maher ER, Brueton LA, Bowdin SC, Luharia A, Cooper W, Cole TR, Macdonald F, Sampson JR, Barratt CL, Reik W \& Hawkins MM 2003 Beckwith-Wiedemann syndrome and assisted reproduction technology (ART). Journal of Medical Genetics $\mathbf{4 0}$ $62-64$.

Mandel H, Szargel R, Labay V, Elpeleg O, Saada A, Shalata A, Anbinder Y, Berkowitz D, Hartman C, Barak M, Eriksson S \& Cohen N 2001 The deoxyguanosine kinase gene is mutated in individuals with depleted hepatocerebral mitochondrial DNA. Nature Genetics 29 337-341.

Marchington DR, Hartshorne GM, Barlow D \& Poulton J 1997 Homopolymeric tract heteroplasmy in mtDNA from tissues and single oocytes: support for a genetic bottleneck. American Journal of Human Genetics 60 408-416.

Meirelles FV \& Smith LC 1997 Mitochondrial genotype segregation in a mouse heteroplasmic lineage produced by embryonic karyoplast transplantation. Genetics 145 445-451.

Meirelles FV \& Smith LC 1998 Mitochondrial genotype segregation during preimplantation development in mouse heteroplasmic embryos. Genetics 148 877-883.

Meirelles FV, Bordignon V, Watanabe $\mathrm{Y}$, Watanabe M, Dayan A, Lobo RB, Garcia JM \& Smith LC 2001 Complete replacement of the mitochondrial genotype in a Bos indicus calf reconstructed by nuclear transfer to a Bos taurus oocyte. Genetics 158 351-356.

Michaels GS, Hauswirth WW \& Laipis PJ 1982 Mitochondrial DNA copy number in bovine oocytes and somatic cells. Developmental Biology 94 246-251.

Miller FJ, Rosenfeldt FL, Zhang C, Linnane AW \& Nagley P 2003 Precise determination of mitochondrial DNA copy number in human skeletal and cardiac muscle by a PCR-based assay: lack of change of copy number with age. Nucleic Acids Research 31 E61.

Moraes CT, Kenyon L \& Hao H 1999 Mechanisms of human mitochondrial DNA maintenance: the determining role of primary sequence and length over function. Molecular Biology of the Cell $103345-3356$.

Moyes CD, Battersby BJ \& Leary SC 1998 Regulation of muscle mitochondrial design. Journal of Experimental Biology 201 299-307.

Nagao $Y$, Totsuka Y, Atomi Y, Kaneda H, Lindahl KF, Imai H \& Yonekawa H 1998 Decreased physical performance of congenic mice with mismatch between the nuclear and mitochondrial genome. Genes and Genetic Systems 73 21-27.

Piko L \& Taylor KD 1987 Amounts of mitochondrial DNA and abundance of some mitochondrial gene transcripts in early mouse embryos. Developmental Biology 123 364-374.

Poulton J 1995 Transmission of mtDNA: cracks in the bottleneck. American Journal of Human Genetics 57 224-226.

Poulton J, Morten K, Freeman-Emmerson C, Potter C, Sewry C, Dubowitz V, Kidd H, Stephenson J, Whitehouse W, Hansen FJ et al. 1994 Deficiency of the human mitochondrial transcription factor h-mtTFA in infantile mitochondrial myopathy is associated with mtDNA depletion. Human Molecular Genetics 3 $1763-1769$. 
Reik W \& Dean W 2003 Gene expression: silent clones speak up. Nature 423 390-391.

Reynier P, May-Panloup P, Chretien MF, Morgan CJ, Jean M, Savagner F, Barriere P \& Malthiery Y 2001 Mitochondrial DNA content affects the fertilizability of human oocytes. Molecular Human Reproduction 7 425-429.

Saada A, Shaag A, Mandel H, Nevo Y, Eriksson S \& Elpeleg O 2001 Mutant mitochondrial thymidine kinase in DNA depletion myopathy. Nature Genetics 29 342-344.

Schon EA, Rizzuto R, Moraes CT, Nakase H, Zeviani M \& DiMauro S 1989 A direct repeat is a hotspot for large-scale deletion of human mitochondrial DNA. Science 244 346-349.

Schutz MM, Vanraden PM \& Wiggans GR 1994 Genetic variation in lactation means of somatic cell scores from six breeds of dairy cattle. Journal of Dairy Science 77 284-293.

Schwartz M \& Vissing J 2002 Paternal inheritance of mitochondrial DNA. New England Journal of Medicine 347 576-580.

Shi W, Zakhartchenko V \& Wolf E 2003 Epigenetic reprogramming in mammalian nuclear transfer. Differentiation 7191.

Shitara H, Hayashi JI, Takahama S, Kaneda H \& Yonekawa H 1998 Maternal inheritance of mouse mtDNA in interspecific hybrids: segregation of the leaked paternal mtDNA followed by the prevention of subsequent paternal leakage. Genetics $\mathbf{1 4 8}$ $851-857$.

Shitara H, Kaneda H, Sato A, Iwasaki K, Hayashi J, Taya C \& Yonekawa H 2001 Non-invasive visualization of sperm mitochondria behavior in transgenic mice with introduced green fluorescent protein (GFP). FEBS Letters $\mathbf{5 0 0}$ 7-11.

Shoffner JM, Lott MT, Lezza AM, Seibel P, Ballinger SW \& Wallace DC 1990 Myoclonic epilepsy and ragged-red fiber disease (MERRF) is associated with a mitochondrial DNA tRNA (Lys) mutation. Cell 61 931-937.

Sligh JE, Levy SE, Waymire KG, Allard P, Dillehay DL, Nusinowitz S, Heckenlively JR, MacGregor GR \& Wallace DC 2000 Maternal germ-line transmission of mutant mtDNAs from embryonic stem cell-derived chimeric mice. PNAS 97 14461-14466.

Smith LC \& Alcivar AA 1993 Cytoplasmic inheritance and its effects on development and performance. Journal of Reproduction and Fertility Supplement $\mathbf{4 8} 31-43$.

Steinborn R, Zakhartchenko V, Jelyazkov J, Klein D, Wolf E, Muller M \& Brem G 1998a Composition of parental mitochondrial DNA in cloned bovine embryos. FEBS Letters 426 352-356.

Steinborn R, Zakhartchenko V, Wolf E, Muller M \& Brem G $1998 b$ Non-balanced mix of mitochondrial DNA in cloned cattle produced by cytoplast-blastomere fusion. FEBS Letters $\mathbf{4 2 6}$ 357-361.

Steinborn R, Schinogl P, Wells DN, Bergthaler A, Muller M \& Brem G 2002 Coexistence of Bos taurus and B. indicus mitochondrial DNAs in nuclear transfer-derived somatic cattle clones. Genetics $162823-829$.

St John JC 2002 Ooplasm donation in humans: the need to investigate the transmission of mitochondrial DNA following cytoplasmic transfer. Human Reproduction 17 1954-1958.

St John JC \& Barratt CLR 1997 Use of anucleate donor oocyte cytoplasm in recipient eggs. The Lancet 350 961-962.
St John J, Sakkas D, Dimitriadi K, Barnes A, Maclin V, Ramey J, Barratt C \& De Jonge C 2000 Abnormal human embryos show a failure to eliminate paternal mitochondrial DNA. The Lancet 355 200.

Sutovsky P, Moreno RD, Ramalho-Santos J, Dominko T, Simerly C \& Schatten G 1999 Ubiquitin tag for sperm mitochondria. Nature $402371-372$.

Takeda K, Takahashi S, Onishi A, Goto Y, Miyazawa A \& Imai H 1999 Dominant distribution of mitochondrial DNA from recipient oocytes in bovine embryos and offspring after nuclear transfer. Journal of Reproduction and Fertility 116 253-259.

Takeda K, Akagi S, Kaneyama K, Kojima T, Takahashi S, Imai H, Yamanaka M, Onishi A \& Hanada H 2003 Proliferation of donor mitochondrial DNA in nuclear transfer calves (Bos taurus) derived from cumulus cells. Molecular Reproduction and Development 64 $429-437$.

Torroni A, Cruciani F, Rengo C, Sellitto D, Lopez-Bigas N, Rabionet R, Govea N, Lopez De Munain A, Sarduy M, Romero L, Villamar M, del Castillo I, Moreno F, Estivill X \& Scozzari R 1999 The A1555G mutation in the 12S rRNA gene of human mtDNA: recurrent origins and founder events in families affected by sensorineural deafness. American Journal of Human Genetics 65 $1349-1358$.

Van Blerkom J, Sinclair J \& Davis P 1998 Mitochondrial transfer between oocytes: potential applications of mitochondrial donation and the issue of herteroplasmy. Human Reproduction 13 2857-2868.

Van Blerkom J, Davis P \& Alexander S 2000 Differential mitochondrial distribution in human pronuclear embryos leads to disproportionate inheritance between blastomeres: relationship to microtubular organization, ATP content and competence. Human Reproduction 15 2621-2633.

Van Goethem G, Dermaut B, Lofgren A, Martin JJ \& Van Broeckhoven C 2001 Mutation of POLG is associated with progressive external opthalmoplegia characterized by mtDNA deletions. Nature Genetics 28 211-212.

Wakayama T \& Yanagimachi R 2001 Effect of cytokinesis inhibitors, DMSO and the timing of oocyte activation on mouse cloning using cumulus cell nuclei. Reproduction 122 49-60.

Wallace DC, Singh G, Lott MT, Hodge JA, Schurr TG, Lezza AM, Elsas LJ 2nd \& Nikoskelainen EK 1988 Mitochondrial DNA mutation associated with Leber's hereditary optic neuropathy. Science 242 1427-1430.

Wiesner RJ, Ruegg JC \& Morano I 1992 Counting target molecules by exponential polymerase chain reaction: copy number of mitochondrial DNA in rat tissues. Biochemical and Biophysics Research Communications 183 553-559.

Wilmut I, Schnieke AE, McWhir J, Kind AJ \& Campbell KH 1997 Viable offspring derived from fetal and adult mammalian cells. Nature 386200.

Zhang $\mathbf{H}$, Cooney DA, Sreenath A, Zhan Q, Agbaria R, Stowe EE, Fornace AJ Jr \& Johns DG 1994 Quantitation of mitochondrial DNA in human lymphoblasts by a competitive polymerase chain reaction method: application to the study of inhibitors of mitochondrial DNA content. Molecular Pharmacology 46 1063-1069. 